\title{
Predicting soil water repellency using hydrophobic organic compounds and their vegetation origin
}

\author{
J. Mao ${ }^{1,2}$, K. G. J. Nierop ${ }^{2}$, M. Rietkerk ${ }^{1}$, and S. C. Dekker ${ }^{1}$ \\ ${ }^{1}$ Copernicus Institute of Sustainable Development - Environmental Sciences, Faculty of Geosciences, \\ Utrecht University, Heidelberglaan 2, P.O. Box 80115, 3508 TC Utrecht, the Netherlands \\ ${ }^{2}$ Department of Earth Sciences - Organic Geochemistry, Faculty of Geosciences, Utrecht University, \\ Heidelberglaan 2, P.O. Box 80115, 3508 TC Utrecht, the Netherlands
}

Correspondence to: J. Mao (j.mao@uu.nl)

Received: 9 February 2015 - Published in SOIL Discuss.: 24 February 2015

Revised: 27 May 2015 - Accepted: 31 May 2015 - Published: 9 June 2015

\begin{abstract}
It is widely accepted that soil water repellency (SWR) is mainly caused by plant-derived hydrophobic organic compounds in soils; such hydrophobic compounds are defined as SWR markers. However, the detailed influence of SWR markers on SWR is yet unclear and the knowledge of their original sources is still limited. The aims of this study are to select important SWR markers to predict SWR based on their correlation with SWR and to determine their origin. In our study, sandy soils with different SWR were collected, along with their covering vegetation, i.e. plant leaves/needles and roots. A sequential extraction procedure was applied to the soils to obtain three organic fractions: dichloromethane (DCM)/MeOH soluble fraction (D), DCM/MeOH insoluble fraction of isopropanol/ammonia solution (IPA/ $\mathrm{NH}_{3}$ ) extract (AI) and $\mathrm{DCM} / \mathrm{MeOH}$ soluble fraction of IPA/ $\mathrm{NH}_{3}$ extract (AS), which were subdivided into 10 dominant SWR marker groups: D fatty acid, D alcohol, D alkane, AI fatty acid, AI alcohol, AI $\omega$-hydroxy fatty acid, AI $\alpha, \omega$-dicarboxylic acid, AS fatty acid, AS alcohol and AS $\omega$ hydroxy fatty acid. Waxes and biopolyesters of the vegetation were also sequentially extracted from plants. The soils with higher SWR have significantly higher relative concentrations of AS alcohols. A number of indications suggest that AS alcohols are mainly derived from roots and most likely produced by microbial hydrolysis of biopolyesters (mainly suberins). In addition, the strong correlation between the biomarkers of plant tissues and SWR markers in soils suggests that it is more accurate to predict SWR of topsoils using ester-bound alcohols from roots, and to predict SWR of subsoils using root-derived $\omega$-hydroxy fatty acids and $\alpha, \omega$-dicarboxylic acids. Considering the sandy soils studied here, the relationships we obtained need to be tested for other types of soils. Our analysis indicates that plant roots have a primary role influencing SWR relative to plant leaves.
\end{abstract}

\section{Introduction}

Soil water repellency (SWR) is one of the important properties that can interrupt soil water infiltration and potentially lead to soil erosion, and occurs globally in a wide range of soil types under various kinds of vegetation (Franco et al., 1995, 2000; Doerr et al., 2000, 2005; Michel et al., 2001; Poulenard et al., 2004; Hansel et al., 2008; de Blas et al., 2010). SWR is caused by hydrophobic organic compounds in soils. These compounds originate from vegetation (McGhie and Posner, 1981; Bisdom et al., 1993; de Blas et al., 2010; Horne and McIntosh, 2000) or microorganisms (Bond and
Harris, 1964; McGhie and Posner, 1980) and have been defined as SWR markers by Mao et al. (2014). Different groups of SWR markers have been isolated from water repellent soils by a number of extraction techniques with selective organic solvents and have been identified by using several types of analytical instruments in previous research (Ma'shum et al., 1988; Franco et al., 1995, 2000; Hansel et al., 2008; Atanassova and Doerr, 2010; de Blas et al., 2010; Mao et al., 2014).

Although numerous SWR markers have been identified, the relationship between these markers and the severity of 
SWR is still not clear. Significantly more organic matter was found in water repellent soils than in wettable soils, but there was no clear correlation between the extracted amounts of organic matter and SWR severity (Atanassova and Doerr, 2010; Mainwaring et al., 2004, 2013). Few studies have attempted to explain the possible relationship between hydrophobic organic compounds and SWR. De Blas et al. (2013) found a significant correlation between the amount of free lipids and SWR; however, the amount of bound lipids did not correlate with soil hydrophobicity. Ester-bound biopolymers (in particular suberins) have been shown to lead to relatively stronger SWR compared to free lipids in sandy soils (Mao et al., 2014). Hence, it is clear that not only the amount but also the type of SWR markers affect the severity of SWR (Contreras et al., 2008; de Blas et al., 2013).

The severity of SWR significantly varies depending on vegetation species and soil depths (Doerr et al., 2002, 2005; Buczko et al., 2005; de Blas et al., 2010, 2013; Neris et al., 2012; Mao et al., 2014; Zavala et al., 2014). For instance, soil under eucalyptus always showed more severe water repellency than under pine during dry periods in northwest Spain (Rodríguez-Alleres and Benito, 2011, 2012). Morley et al. (2005) found large variations in SWR from extremely repellent to non-repellent sandy soil under grasses, at depths ranging from 0 to $40 \mathrm{~cm}$. As vegetation is the primary input of organic matter to soils (Van Bergen et al., 1997; KögelKnabner, 2002), it is now well accepted that SWR is mainly the result of accumulated hydrophobic organic compounds in soils originally derived from vegetation (Bisdom et al., 1993; DeBano, 2000; Doerr et al., 2000; Horne and McIntosh, 2000; Hansel et al., 2008; de Blas et al., 2010, 2013) and to a smaller extent from microbes (Hallett and Young, 1999; Feeney et al., 2006).

In this paper we aim to predict SWR based on the occurrence of different types and amounts of SWR markers in sandy soils and to understand and link the SWR markers to their origin, i.e. the vegetation type (leaf or root). We therefore use sandy soils under different vegetation types similar to our previous study (Mao et al., 2014), which the soils contain more than 100 different SWR markers. Sandy soils have been chosen because they contain barely any organomineral complexes, leading to negligible interactions between soil particles and organic matter, in contrast to clay or silt soils (Schulten and Leinweber, 2000; Kleber et al., 2007). To predict SWR from specific leaf/root biomarkers, we apply linear regression data analysis to the SWR markers both as individual compounds and combined in compound groups from the three different fractions: dichloromethane (DCM)/MeOH soluble fraction (D), DCM/MeOH insoluble fraction of IPA/ $\mathrm{NH}_{3}$ extract (AI) and $\mathrm{DCM} / \mathrm{MeOH}$ soluble fraction of IPA/ $\mathrm{NH}_{3}$ extract (AS), as analysed by Mao et al. (2014).

\section{Materials and methods}

\subsection{Sampling}

The sand dunes of the Zuid-Kennemerland National Park in the Netherlands were chosen as a sampling site. Soils and vegetation samples were collected along two perpendicular transects, with a variety of vegetation cover. All the soils were classified as Cambic Arenosols (FAO, 2006), and more details on the soil characteristics and transects are given in Mao et al. (2014). The soils were sampled from maximal three different soil horizons at spots under different types of vegetation (Table 1). The living plant leaves and roots were taken separately from each vegetation species, except for sheep fescue, of which the roots found in the filed were very fine and therefore it was decided to collect the leaves and roots together. All collected soils were oven-dried at $30^{\circ} \mathrm{C}$ for $48 \mathrm{~h}$, and passed a $1.4 \mathrm{~mm}$ diameter sieve to remove large leaf and root fragments. All vegetation samples were freezedried and stored in a dry place prior to further analysis.

\subsection{Soil characteristics measurements}

A $1: 2.5(w / w)$ soil-to-water ratio was used to determine soil $\mathrm{pH}$ value (Metson, 1956), which was measured by using a $\mathrm{pH}$ meter (Consort C830). To determine total organic carbon (TOC) and total nitrogen (TN), all soils were decalcified using $1 \mathrm{M} \mathrm{HCl}$ to remove inorganic carbon (Van Wesemael, 1955) and ground into fine powder by using planetary ball mills (Pulverisette ${ }^{\circledR} 5$, Fritsch). The TOC and TN contents of the soils were measured using a CNS analyser (Fisons Instruments NA1500).

\subsection{Water repellency assessment}

The water drop penetration time (WDPT) test is widely accepted and used to evaluate the extent of SWR (Van't Woudt, 1959; Krammes and DeBano, 1965; Wessel, 1988; Dekker and Ritsema, 1994; Doerr et al., 2005). To obtain the WDPT of all oven-dried soils before extraction, the WDPT value of each soil was determined based on the average penetration time of 20 individual water droplets. Based on the WDPT method, the severity of SWR was classified as follows: wettable $(<5 \mathrm{~s})$, slightly repellent $(5-60 \mathrm{~s})$, strongly repellent (60-600 s), severely repellent (600-3600 s) and extremely repellent (> 3600 s) (Bisdom et al., 1993; Dekker and Ritsema, 1996). The repellency classes of all the soils are presented in Table 1.

\subsection{Soil and vegetation extraction}

To investigate different fractions of SWR markers, sequential extraction methods have been applied to all the soils (see for details Mao et al., 2014) and vegetation samples. To isolate free lipids from the soils and the plants, the ovendried soils, leaves and roots were weighed and extracted us- 
Table 1. Soil profile and vegetation description.

\begin{tabular}{|c|c|c|c|c|c|c|c|c|c|c|c|c|}
\hline Profile & $\begin{array}{l}\text { Sample } \\
\text { label }\end{array}$ & $\begin{array}{l}\text { Sampling } \\
\text { depth }(\mathrm{cm})\end{array}$ & Horizon & $\mathrm{pH}$ & $\begin{array}{r}\text { TOC } \\
\left(\mathrm{mg} \mathrm{g}^{-1} \text { soil }\right)^{\mathrm{c}}\end{array}$ & $\begin{array}{r}\mathrm{TN} \\
\left(\mathrm{mg} \mathrm{g}^{-1} \text { soil }\right)\end{array}$ & $\begin{array}{r}\mathrm{C} / \mathrm{N} \\
\text { ratio }\end{array}$ & $\begin{array}{r}\text { WDPT }^{\mathrm{d}} \\
(\mathrm{s})\end{array}$ & $\begin{array}{r}\log _{10} \\
\text { WDPT } \\
\text { (s) }\end{array}$ & $\begin{array}{l}\text { Repellency } \\
\text { class }\end{array}$ & Vegetation & Vegetation sampled \\
\hline \multirow[t]{3}{*}{1} & WRC- $1^{\mathrm{a}}$ & $0-7$ & A & 8.79 & 0.76 & 0.16 & 4.82 & 0 & -1.00 & wettable & Festuca sp. (sheep fescue) & Leaves combined with roots \\
\hline & WRC-2 & $7-14$ & $\mathrm{Ahb}^{\mathrm{b}}$ & 8.33 & 4.83 & 0.51 & 9.54 & 35 & 1.55 & slight & Festuca sp. & \\
\hline & WRC-3 & $14-20$ & B & 8.72 & 1.40 & 0.25 & 5.66 & 0.3 & -0.48 & wettable & Festuca sp. & \\
\hline 2 & WRC-6 & $0-1$ & A & 8.26 & 3.47 & 0.38 & 9.20 & 1 & 0.00 & wettable & Algae & None \\
\hline \multirow[t]{2}{*}{3} & WRC-8 & $0-5$ & $\mathrm{Ah}$ & 7.87 & 5.49 & 0.49 & 11.15 & 148 & 2.17 & strong & Hypnum lacunosum (hypnum moss) & Whole moss plants \\
\hline & WRC-9 & $5-10$ & B & 8.70 & 1.57 & 0.25 & 6.21 & 2 & 0.36 & wettable & Hурпит lacunosum & \\
\hline 4 & WRC-10 & $0-10$ & $\mathrm{Ah}$ & 6.92 & 26.80 & 2.00 & 13.42 & 18 & 1.25 & slight & Hypnum lacunosum & \\
\hline 5 & WRC-13 & $0-16$ & $\mathrm{Ah}$ & 5.84 & 14.98 & 1.01 & 14.80 & 240 & 2.38 & strong & Pinus nigra (black pine) & Green needles and roots \\
\hline \multirow[t]{2}{*}{6} & WRC-14 & $0-9$ & $\mathrm{Ah}$ & 7.09 & 31.08 & 2.40 & 12.96 & 417 & 2.62 & strong & Crataegus sp. (hawthorn) & Leaves and roots \\
\hline & WRC-15 & $9-15$ & B & 7.55 & 5.02 & 0.53 & 9.49 & 550 & 2.74 & strong & Crataegus sp. & \\
\hline \multirow[t]{2}{*}{7} & WRC-25 & $0-7$ & $\mathrm{Ah}$ & 7.66 & 10.22 & 0.82 & 12.47 & 4786 & 3.68 & extreme & Hippophae rhamnoides (sea-buckthorn) & Leaves and roots \\
\hline & WRC-26 & $7-12$ & B & 8.10 & 4.77 & 0.45 & 10.57 & 331 & 2.52 & strong & Hippophae rhamnoides & \\
\hline \multirow[t]{3}{*}{8} & WRC-30 & $0-2$ & Ah1 & 5.76 & 87.44 & 6.35 & 13.77 & 1905 & 3.28 & severe & Quercus robur (common oak) & Leaves and roots \\
\hline & WRC-31 & $2-4.5$ & $\mathrm{Ah} 2$ & 5.79 & 20.71 & 1.59 & 13.04 & 2512 & 3.40 & severe & Quercus robur & \\
\hline & WRC-32 & $4.5-20$ & B & 8.08 & 2.46 & 0.27 & 9.05 & 14 & 1.14 & slight & Quercus robur & \\
\hline
\end{tabular}

ing dichloromethane/methanol (DCM/MeOH $(9: 1, v: v))$ by using a Soxhlet apparatus for $24 \mathrm{~h}$ to give the D fraction (Bull et al., 2000a, b; Nierop et al., 2005; Jansen et al., 2006). The residual soils were air-dried and extracted using a Soxhlet apparatus containing isopropanol/ammonia solution (IPA/ $\mathrm{NH}_{3}, 7: 3(v: v), 32 \%$ ammonia solution) for $48 \mathrm{~h}$. The soils became wettable after IPA/ $\mathrm{NH}_{3}$ extraction. The soluble lipids (AS fraction) were separated from the dried IPA/ $\mathrm{NH}_{3}$ extracts by $\mathrm{DCM} / \mathrm{MeOH}(9: 1)$, and the residues resulted in AI fractions, which involved ester bonds.

All the D and AS fractions of the soils and DCM/MeOH extracts of the plants were methylated using diazomethane $\left(\mathrm{CH}_{2} \mathrm{~N}_{2}\right)$. The AI fractions and the lipid-free air-dried leaves and roots were depolymerised through trans-methylation using $\mathrm{BF}_{3}-\mathrm{MeOH}$ at $70^{\circ}$ for $16 \mathrm{~h}$ (Riederer et al., 1993). Prior to analysis, all the aliquots were eluted through a small silica gel 60 column (0.063-0.2 mm diameter, 79-230 mesh) with ethyl acetate and silylated using N,O-bis (trimethylsilyl) trifluoroacetamide (BSTFA) in pyridine at $60^{\circ}$ for $20 \mathrm{~min}$.

\subsection{Gas chromatography (GC) and GC-mass spectrometry (MS) analysis}

A HP 6890 Series GC fitted with a flame ionisation detector (FID) was used to analyse derivatised extracts. A CP-Sil 5 CB capillary column (Agilent Technologies, $30 \mathrm{~m}$ length $\times 0.32 \mathrm{~mm}$ diameter, $0.10 \mu \mathrm{m}$ film thickness) was used to separate compounds, using helium as carrier gas with a constant pressure at $100 \mathrm{kPa}$. The oven heating programme started with an initial temperature of $70^{\circ}$, increased to $130^{\circ}$ at $20^{\circ} \mathrm{min}^{-1}$, then heated from 130 to $320^{\circ}$ at $4^{\circ} \mathrm{min}^{-1}$, and finally held at $320^{\circ}$ for $20 \mathrm{~min}$.

GC-MS analysis of extracts was performed on a Thermo Trace GC Ultra GC connected to Finnigan Trace DSQ mass spectrometer with a mass range of $m / z 50-800$, using helium at a $1.0 \mathrm{~mL} \mathrm{~min}^{-1}$ flow rate as the carrier gas. The GC-MS was equipped with a similar capillary column as the GC-FID, and the same oven temperature mode was used as for the GCFID analysis.
Based on GC-FID and GC-MS analyses, the relative response factors of compound groups (alkanes, alcohols, fatty acids, $\omega$-hydroxy fatty acids and $\alpha, \omega$-dicarboxylic acids) were rather similar and barely discriminated between various types of compounds. Therefore, a known amount of squalane as an internal standard was added to extracts to quantify compounds by peak area integration from GC-MS chromatograms to correct for possible co-eluting compounds. $1 \mu \mathrm{L}$ of derivatised extracts was injected onto the column for both GC-FID and GC-MS analyses. Compound identification was conducted on mass spectra using a NIST library or by interpretation of the spectra, and combined with their retention times or by comparison with literature data.

\subsection{Statistical data analysis}

The correlation between SWR markers and SWR can be clearly interpreted by linear regression analysis. Here we applied simple linear regression between measured SWR value (i.e. the WDPT) at the $\log$ scale $(\log (s))$ to the concentrations of individual SWR markers and each compound group. To assess both the quantitative and qualitative effects, we carried out regression analysis on the absolute amount $\left(\mu \mathrm{g} \mathrm{g}^{-1}\right.$ soil) and the relative amount ( $\left.\mu \mathrm{g} \mathrm{g}^{-1} \mathrm{TOC}\right)$ of SWR markers. In our study, the quantity of every compound group was defined as an absolute amount ( $\mu \mathrm{g} \mathrm{g}^{-1}$ soil), and the quality as the ratio of the concentrations of two different compound groups (Group1/Group2, [-]). We distinguish these functional compound groups based on the extraction type $(\mathrm{D}, \mathrm{AI}$ and AS) and their compound types, i.e. alkanes, fatty acids, alcohols, $\omega$-hydroxy fatty acids or $\alpha, \omega$-dicarboxylic acids. 
Table 2. The relative concentrations $\left(\log \left(\mu \mathrm{g} \mathrm{g}^{-1} \mathrm{TOC}\right)\right)$ of single SWR markers significantly related to SWR.

\begin{tabular}{|c|c|c|c|c|c|c|}
\hline \multirow[b]{3}{*}{ SWR marker ${ }^{\mathrm{a}}$} & \multicolumn{6}{|c|}{ Soil category } \\
\hline & \multicolumn{2}{|c|}{ All soils $(n=15)$} & \multicolumn{2}{|c|}{ Topsoils $(n=10)$} & \multicolumn{2}{|c|}{ Subsoils $(n=5)$} \\
\hline & Coef. ${ }^{b}$ & Sig. $^{\mathrm{c}}$ & Coef. & Sig. & Coef. & Sig. \\
\hline $\mathrm{D} \mathrm{C}_{16}$ fatty acid & -0.811 & 0.000 & -0.905 & 0.000 & & \\
\hline $\mathrm{D} \mathrm{C}_{17}$ fatty acid & -0.612 & 0.015 & -0.730 & 0.017 & & \\
\hline $\mathrm{D} \mathrm{C}_{18}$ fatty acid & -0.768 & 0.001 & -0.811 & 0.004 & & \\
\hline $\mathrm{D} \mathrm{C}_{21}$ fatty acid & -0.555 & 0.032 & & & & \\
\hline $\mathrm{D} \mathrm{C}_{15}$ alcohol & -0.741 & 0.002 & -0.873 & 0.001 & -0.940 & 0.017 \\
\hline $\mathrm{D} \mathrm{C}_{16}$ alcohol & -0.675 & 0.006 & -0.662 & 0.037 & & \\
\hline $\mathrm{D} \mathrm{C}_{17}$ alcohol & -0.729 & 0.002 & -0.756 & 0.011 & & \\
\hline $\mathrm{D} \mathrm{C}_{18}$ alcohol & -0.581 & 0.023 & & & -0.951 & 0.013 \\
\hline $\mathrm{D} \mathrm{C}_{24}$ alcohol & 0.575 & 0.025 & & & & \\
\hline $\mathrm{D} \mathrm{C}_{20}$ alkane & -0.797 & 0.000 & -0.819 & 0.004 & & \\
\hline $\mathrm{D} \mathrm{C}_{23}$ alkane & -0.571 & 0.026 & & & & \\
\hline $\mathrm{D} \mathrm{C}_{24}$ alkane & -0.670 & 0.006 & -0.713 & 0.021 & & \\
\hline AI $C_{16}$ fatty acid & -0.547 & 0.035 & -0.659 & 0.038 & & \\
\hline AI $C_{18}$ fatty acid & -0.733 & 0.002 & -0.668 & 0.035 & -0.909 & 0.033 \\
\hline AI $C_{21}$ fatty acid & -0.773 & 0.001 & -0.726 & 0.018 & -0.925 & 0.025 \\
\hline AS $C_{22}$ fatty acid & & & -0.687 & 0.028 & & \\
\hline $\mathrm{AS} \mathrm{C}_{23}$ fatty acid & & & -0.639 & 0.047 & & \\
\hline $\mathrm{AS} \mathrm{C}_{24}$ fatty acid & & & -0.653 & 0.040 & & \\
\hline $\mathrm{AS} \mathrm{C}_{20}$ alcohol & 0.596 & 0.019 & & & & \\
\hline $\mathrm{AS} \mathrm{C}_{24}$ alcohol & 0.613 & 0.015 & & & & \\
\hline $\mathrm{AS} \mathrm{C}_{30}$ alcohol & 0.532 & 0.041 & & & & \\
\hline $\mathrm{AS} \mathrm{C}_{20} \omega$-hydroxy fatty acid & 0.524 & 0.045 & & & & \\
\hline
\end{tabular}

${ }^{\mathrm{a}} \mathrm{D}$, AS and $\mathrm{AI}$ refer to $\mathrm{DCM} / \mathrm{MeOH}$ soluble fraction, $\mathrm{DCM} / \mathrm{MeOH}$ soluble fraction of IPA/NH 3 extract and $\mathrm{DCM} / \mathrm{MeOH}$ insoluble fraction of IPA/NH $\mathrm{NH}_{3}$ extract, respectively. ${ }^{b}$ Linear correlation coefficient. ${ }^{c}$ Significance.

\section{Results}

\subsection{Single compounds analysis}

\subsubsection{Single SWR markers from soils}

For all soils, the majority of compounds had negative but no significant correlations between their relative concentrations ( $\mu \mathrm{g} \mathrm{g}^{-1}$ TOC) and SWR. In Table 2, only the significant correlations between relative concentrations of individual markers and SWR are given, in which we analysed this for (1) all soils, (2) topsoils and (3) subsoils.

For all soils $(n=15)$, in the $\mathrm{D}$ fraction we found that only $\mathrm{C}_{24}$ alcohol to be significantly positively related to SWR $\left(\log _{10}\right.$ WDPT; Table $\left.2 ; r=0.575, p=0.025\right)$. For the AS fraction, three even-numbered alcohols $\left(\mathrm{C}_{20}, \mathrm{C}_{24}\right.$ and $\left.\mathrm{C}_{30}\right)$ and $\mathrm{C}_{20} \omega$-hydroxy fatty acid had significant positive relationships with SWR. Other, in general, short-chain fatty acids, alcohols and alkanes from different fractions exhibited significant negative relationships with SWR (Table 2).

For all the topsoils ( $n=10$ ), the longer-chain AS alcohols $\left(\mathrm{C}_{20}, \mathrm{C}_{24}\right.$ and $\left.\mathrm{C}_{30}\right)$, which had significant relationships with SWR for all soils, were no longer significant in the topsoils. Only negatively related compounds were found for the topsoils. For the AI fraction, similar significant negatively corre- lated markers for the topsoils were found as compared to all soils. For the AS fraction, $\mathrm{C}_{22}, \mathrm{C}_{23}$ and $\mathrm{C}_{24}$ fatty acids had significant negative correlations with SWR for all the topsoils, which could not be found for all soils. In contrast, AS alcohols did not show significant relationships with SWR for the topsoils. For all the subsoils $(n=5)$, short-chain alcohols $\left(\mathrm{C}_{16}\right.$ and $\left.\mathrm{C}_{18}\right)$ in the $\mathrm{D}$ fraction and fatty acids $\left(\mathrm{C}_{18}\right.$ and $\left.\mathrm{C}_{21}\right)$ in the AI fraction showed negatively significant correlations with SWR, while none of the compounds in the AS fraction had a significant correlation with SWR.

\subsubsection{Single biomarkers from vegetation}

The compound groups fatty acids, alcohols and alkanes were identified in $\mathrm{DCM} / \mathrm{MeOH}$ extracts from plant leaves and roots (Fig. 1a-c). Besides these three main groups mentioned above, $\beta$-sitosterol was abundant in all the leaves and roots, but was found in soils with much lower abundance and had an insignificant correlation with SWR, as similar to other identified sterols (e.g. stigmasterol in mosses). Other typical biomarkers were found in leaves and roots of one or more species but found only sparingly among all soils, for instance, dehydroabietic acid in black pine needles, in the leaves of oak and sea-buckthorn, therefore those biomarkers 

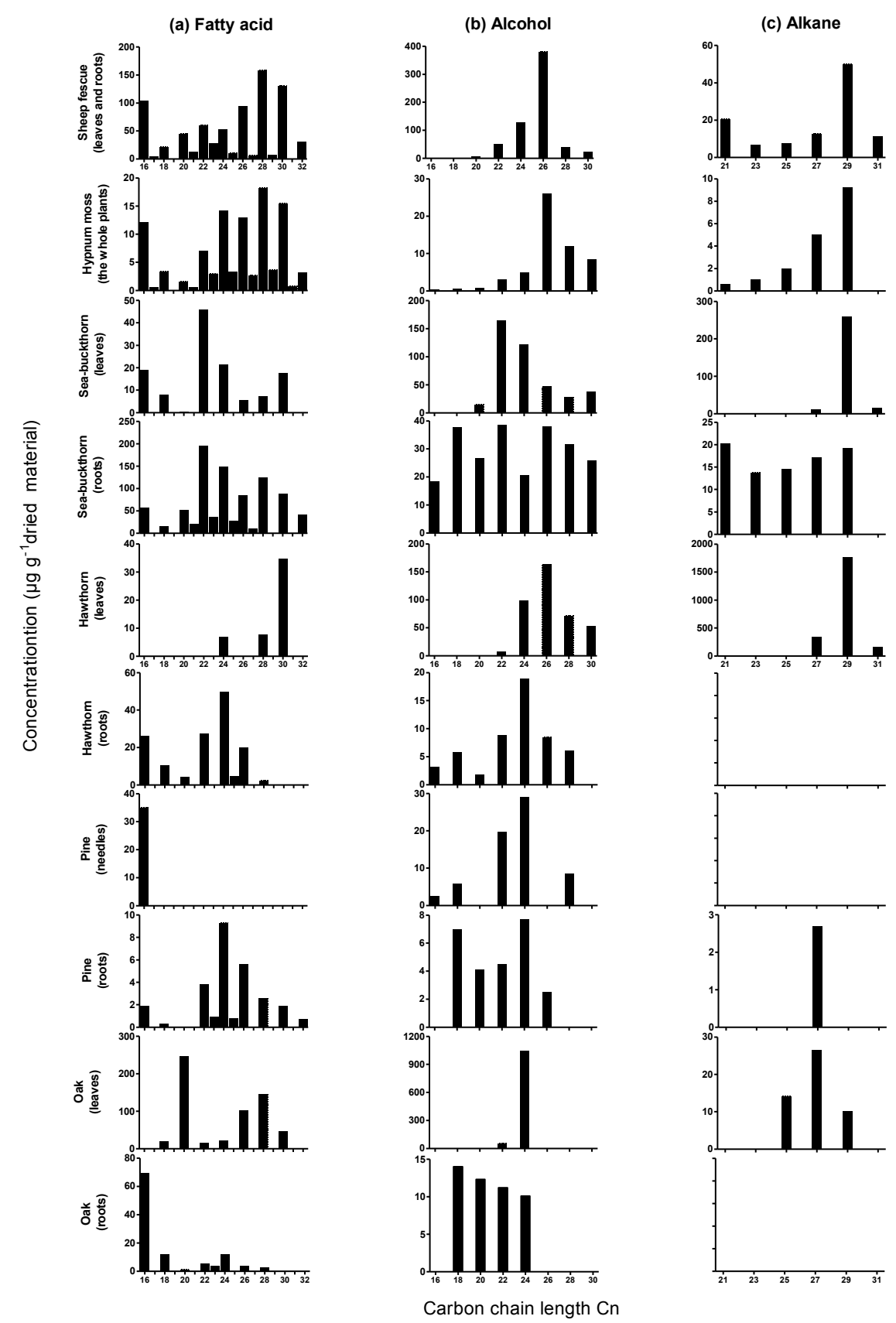

Figure 1. Chain length distribution of DCM/MeOH extractable lipids ( $\mu \mathrm{g} \mathrm{g}^{-1}$ dried material) of vegetation leaves and roots. (a) fatty acids; (b) alcohols; (c) alkanes.

were not taken into account as an SWR marker to predict SWR.

For the fatty acids in all leaves and roots, a strong evenover-odd preference was found, in which chain lengths of most plant extracts ranged between $\mathrm{C}_{16}$ and $\mathrm{C}_{32}$. The sheep fescue and hypnum moss clearly showed the largest range of abundant fatty acids, in which $\mathrm{C}_{28}$ was most abundant for both species. For sea-buckthorn and hawthorn, roots had more diverse kinds of fatty acids than the leaves. $\mathrm{C}_{30}$ was most abundant in leaves of hawthorn, $\mathrm{C}_{24}$ in roots of hawthorn and $\mathrm{C}_{22}$ in both leaves and roots of sea-buckthorn. For pine needles, $\mathrm{C}_{16}$ and $\mathrm{C}_{18}$ fatty acids were the only fatty acids found, while the pine roots contained a large range with $\mathrm{C}_{24}$ dominating. Long-chain even-numbered fatty acids were more abundant in the leaves (with $\mathrm{C}_{20}$ as most dominant) than in the roots of common oak, with $\mathrm{C}_{16}$ as most dominant. In summary, the number of different fatty acids found 
in roots was larger than in leaves, with highest concentrations in sea-buckthorn roots and oak leaves.

In contrast to fatty acids, the alcohols observed in plants ranged between $\mathrm{C}_{16}$ and $\mathrm{C}_{32}$ and were only even-numbered (Fig. 1b). The most abundant alcohol in sheep fescue and hypnum moss was $\mathrm{C}_{26} \cdot \mathrm{C}_{22}$ was the most dominating in seabuckthorn leaves, while in their roots $\mathrm{C}_{18}, \mathrm{C}_{22}$ and $\mathrm{C}_{26}$ alcohols had similar predominance. For hawthorn, $\mathrm{C}_{26}$ was most the abundant in leaves and $\mathrm{C}_{24}$ in roots. $\mathrm{C}_{24}$ alcohol was predominant in pine needles and oak leaves, while their roots showed a more uniform distribution $\left(\mathrm{C}_{18}-\mathrm{C}_{24}\right.$ and $\mathrm{C}_{18}-\mathrm{C}_{26}$, respectively). To summarise, the number of different alcohols found in roots was larger than in the leaves, which is similar as found for the fatty acids, but abundance of the alcohols in the leaves was much higher.

Only long-chain odd-numbered alkanes $\left(\mathrm{C}_{21}-\mathrm{C}_{31}\right)$ were observed in the leaves, except for pine needles in which no alkanes were found (Fig. 1c). $\mathrm{C}_{27}$ dominated oak leaves, $\mathrm{C}_{29}$ dominated all the other leaves and roots except sea-buckthorn roots that were dominated by $\mathrm{C}_{21}$ and had a larger range of alkanes than all other plant tissues. Fatty acids, alcohols, $\omega$ hydroxy fatty acids and $\alpha, \omega$-dicarboxylic acids were released from the ester-bound lipids (cutin and suberin) upon $\mathrm{BF}_{3}-$ $\mathrm{MeOH}$ hydrolysis of all leaves and roots (Fig. 2a-d). In addition, several di- and trihydroxy fatty acids, common cutin and suberin monomers were identified, but as they were barely or not found in our soils (Mao et al., 2014), they do not play a major role in our correlation analysis. Therefore, we limited ourselves to the previously mentioned compound groups.

The even-over-odd-numbered fatty acids $\left(\mathrm{C}_{16}-\mathrm{C}_{30}\right)$ dominated all leaves and roots (Fig. 2a). Interestingly, $\mathrm{C}_{16}$ fatty acid was the most dominating ester-bound fatty acid for all above-ground plant tissues in relative high concentrations, in contrast to the roots. All roots had a large range of fatty acids, dominated by $\mathrm{C}_{24}$, except for hawthorn that contained only $\mathrm{C}_{20}$ and $\mathrm{C}_{22}$ fatty acids.

Compared to leaves, a larger number of ester-bound alcohols in greater abundance were found in the roots. For sheep fescue, $\mathrm{C}_{20}$ alcohol was the dominant one, while $\mathrm{C}_{18}$ was the only one found in hypnum moss (Fig. 2b). No ester-bound alcohol was found in sea-buckthorn and hawthorn leaves. Pine needles only showed $\mathrm{C}_{24}$, while oak leaves showed only $\mathrm{C}_{20}$. The most dominant ester-bound alcohol in the roots of seabuckthorn and pine was $\mathrm{C}_{16}$, while in those of hawthorn and oak were $\mathrm{C}_{24}$ and $\mathrm{C}_{20}$, respectively.

Sheep fescue showed a large range of $\omega$-hydroxy fatty acids dominated by $\mathrm{C}_{18: 1}$ (Fig. 2c), whereas hypnum moss contained only $\mathrm{C}_{16}$. The roots of sea-buckthorn had the widest range of $\omega$-hydroxy fatty acids, from $\mathrm{C}_{16}$ to $\mathrm{C}_{28}$, while the roots of hawthorn had the narrowest range from $\mathrm{C}_{16}$ to $\mathrm{C}_{22}$ excluding $\mathrm{C}_{18: 1} \cdot \mathrm{C}_{24}$ was most dominant for seabuckthorn roots, while in hawthorn roots $\mathrm{C}_{20}$ was most abundant. $\mathrm{C}_{12}$ and $\mathrm{C}_{14} \omega$-hydroxy fatty acids were only observed in pine needles, whereas longer-chain ones $\left(>\mathrm{C}_{18}\right)$ were present only in its roots maximising at $\mathrm{C}_{22} \cdot \mathrm{C}_{18: 1} \omega$-hydroxy fatty acid predominated in both oak leaves and roots.

Even-numbered $\alpha, \omega$-dicarboxylic acids $\left(\mathrm{C}_{16}-\mathrm{C}_{28}\right)$ as typical suberin-derived biomarkers were only found in the plant roots (Fig. 2d). No $\alpha, \omega$-dicarboxylic acids were found in sheep fescue and hypnum moss while in the roots of the other species the dominating $\alpha, \omega$-dicarboxylic acid differs: sea-buckthorn $\left(\mathrm{C}_{18: 1}\right)$, hawthorn $\left(\mathrm{C}_{16}\right)$, oak $\left(\mathrm{C}_{16}\right)$ and pine $\left(\mathrm{C}_{22}\right)$.

\subsubsection{Soil-vegetation link based on single compounds}

Compared to leaves, roots contained a larger number of different extractable and ester-bound biomarkers, except for the alkanes. The concentrations of most extractable lipids in roots were lower than in leaves, while the opposite was generally true for ester-bound lipids.

Comparing the $\mathrm{D}$ fraction with extractable lipids of plants, $\mathrm{C}_{16}, \mathrm{C}_{17}$ and $\mathrm{C}_{18}$ fatty acids in the $\mathrm{D}$ fraction of soils are negatively related to SWR for all soils and the topsoils (Table 2), which were most abundant in sheep fescue (Fig. 1a). The oak leaves contained the highest concentration of $\mathrm{C}_{24}$ alcohol, which in the $\mathrm{D}$ fraction was the only compound that was positively related to SWR. Alcohols $\mathrm{C}_{20}$ and $\mathrm{C}_{24}$ in the ester-bound lipids of the hawthorn roots were most abundant and can clearly be related to $\mathrm{C}_{20}$ and $\mathrm{C}_{24}$ alcohols in the AI fraction of soils.

\subsection{Compound groups analysis}

\subsubsection{SWR marker groups from soils}

To get a more general view of the relationship between certain compounds and SWR, we have analysed compound groups (i.e. sum of all compounds of the same type). For all soils, the absolute total amounts of the main compound groups in the D, AI and AS fractions ranged from 1.61 to $63.80 \mathrm{mg} \mathrm{g}^{-1}$ soil, from 0.84 to $62.18 \mathrm{mg} \mathrm{g}^{-1}$ soil and from 0.27 to $40.24 \mathrm{mg} \mathrm{g}^{-1}$ soil, respectively. For all soils, all compound groups, i.e. D fatty acid, D alcohol, D alkane, AI fatty acid, AI alcohol, AI $\omega$-hydroxy fatty acid, AI $\alpha, \omega$ dicarboxylic acid, AS fatty acid, AS alcohol and AS $\omega$ hydroxy fatty acid, had significant positive relationships between quantity $\left(\log _{10}\left(\mu \mathrm{g} \mathrm{g}^{-1}\right.\right.$ soil $\left.)\right)$ and SWR $\left(\log _{10}\right.$ WDPT) (Table 3). For all the topsoils, all compound groups were significantly correlated with SWR except AI $\alpha, \omega$-dicarboxylic acid and AS fatty acid. For all the subsoils, less compound groups had significant relationships with SWR. For the high TOC soils, no group had a significant correlation with SWR, while for the low TOC soils, all groups were significantly related to SWR except AI fatty acid and AS $\omega$-hydroxy fatty acid.

As absolute values highly correlate with organic matter content and therefore with SWR, relative amounts are more interesting to understand the importance of one component over the other. For all soils, the relative total amounts 


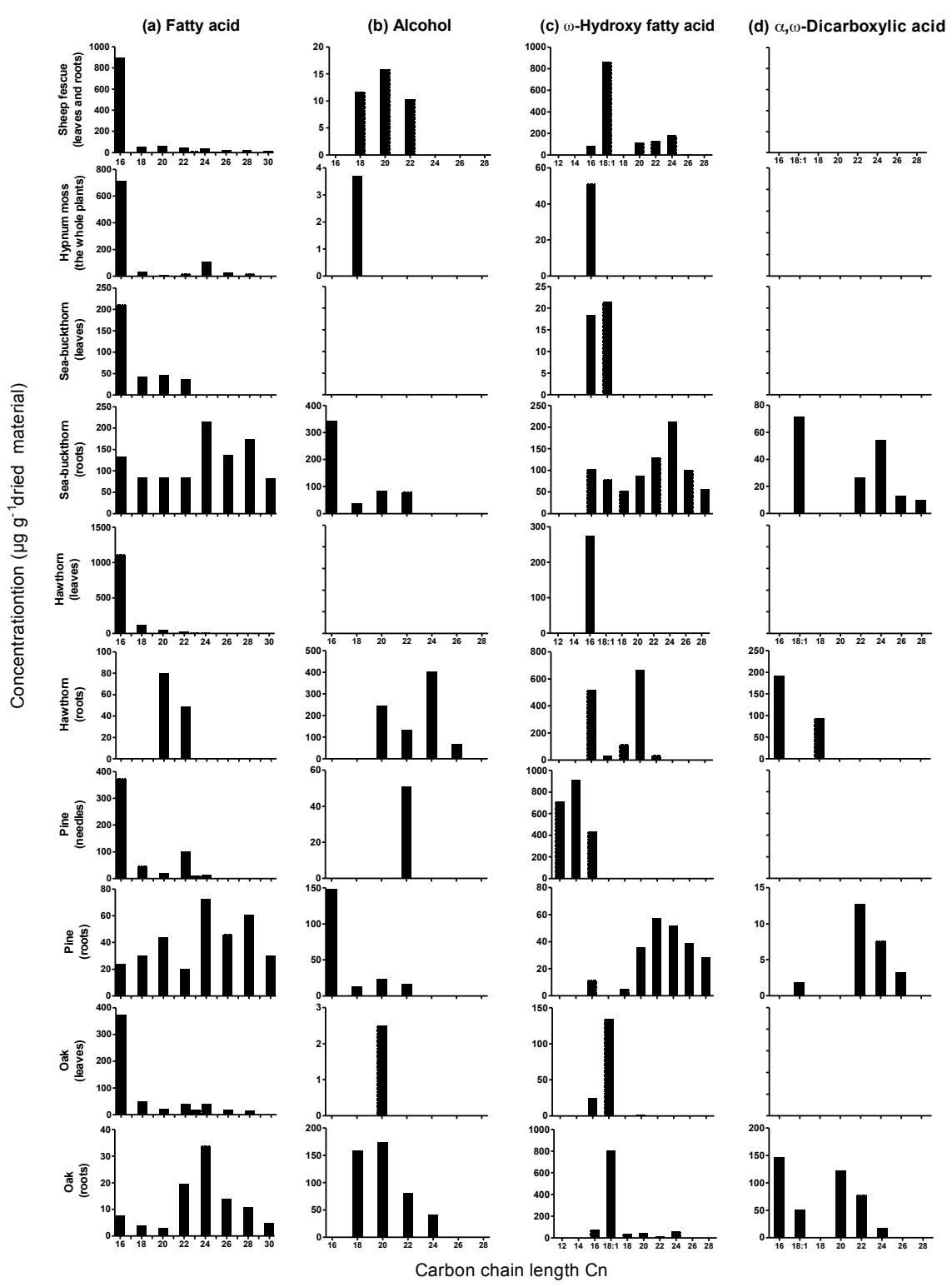

Figure 2. Chain length distribution of ester-bound lipids ( $\mu \mathrm{g} \mathrm{g}^{-1}$ dried material) upon $\mathrm{BF}_{3}-\mathrm{MeOH}$ hydrolysis of vegetation leaves and roots. (a) fatty acids; (b) alcohols; (c) $\omega$-hydroxy fatty acids; (d) $\alpha, \omega$-dicarboxylic acids.

of the main compound groups in the D, AI and AS fractions ranged from 0.74 to $2.74 \mathrm{mg} \mathrm{g}^{-1} \mathrm{TOC}$, from 0.48 to $2.01 \mathrm{mg} \mathrm{g}^{-1} \mathrm{TOC}$ and from 0.24 to $1.43 \mathrm{mg} \mathrm{g}^{-1} \mathrm{TOC}$, respectively. To this end, the correlation between the relative concentrations $\left(\log _{10}\left(\mu \mathrm{g} \mathrm{g}^{-1} \mathrm{TOC}\right)\right)$ of compound groups and SWR was analysed. Only the AS alcohol group had a positive significant correlation for all soils and the subsoils (Table 3). The other groups either had a negative or positive relationship with SWR but not significant. No compound group was significantly related to SWR for the topsoils.

\subsubsection{Vegetation biomarker groups}

Considering the biomarker groups of extractable lipids of sea-buckthorn, hawthorn, pine and oak, oak leaves had much more abundant fatty acids and alcohols than the leaves of other plants (Table 4). The roots of sea-buckthorn were richer in fatty acids and alcohols than the other roots. Alkanes were observed in all leaves except pine needles, whereas a relatively small amount of alkanes was found in pine roots. The leaves of hawthorn had the highest amount of alkane while no alkanes were found in its roots. Sea-buckthorn was the only plant species containing alkanes in both its leaves and roots. 
Table 3. Correlation coefficients of single SWR marker groups significantly $(<0.05)$ related to SWR

\begin{tabular}{|c|c|c|c|c|c|c|}
\hline \multirow[b]{2}{*}{ Soil category } & \multicolumn{3}{|c|}{ Absolute amount $\left(\log \left(\mu \mathrm{g} \mathrm{g}^{-1}\right.\right.$ soil $\left.)\right)$} & \multicolumn{3}{|c|}{ Relative amount $\left(\log \left(\mu \mathrm{g} \mathrm{g}^{-1} \mathrm{TOC}\right)\right)$} \\
\hline & SWR marker ${ }^{\mathrm{a}}$ & Coef. ${ }^{b}$ & Sig. ${ }^{\mathrm{c}}$ & SWR marker & Coef. & Sig. \\
\hline \multirow[t]{10}{*}{ All soils } & D fatty acid & 0.797 & 0.000 & AS alcohol & 0.696 & 0.004 \\
\hline & D alcohol & 0.777 & 0.001 & & & \\
\hline & D alkane & 0.778 & 0.001 & & & \\
\hline & AI fatty acid & 0.694 & 0.004 & & & \\
\hline & AI alcohol & 0.758 & 0.001 & & & \\
\hline & AI $\omega$-hydroxy fatty acid & 0.701 & 0.004 & & & \\
\hline & AI $\alpha, \omega$-dicarboxylic acid & 0.650 & 0.009 & & & \\
\hline & AS fatty acid & 0.624 & 0.013 & & & \\
\hline & AS alcohol & 0.821 & 0.000 & & & \\
\hline & AS $\omega$-hydroxy fatty acid & 0.543 & 0.037 & & & \\
\hline \multirow[t]{8}{*}{ Top soils } & D fatty acid & 0.796 & 0.006 & None & & \\
\hline & D alcohol & 0.780 & 0.008 & & & \\
\hline & D alkane & 0.779 & 0.008 & & & \\
\hline & AI fatty acid & 0.688 & 0.028 & & & \\
\hline & AI alcohol & 0.740 & 0.014 & & & \\
\hline & AI $\omega$-hydroxy fatty acid & 0.675 & 0.032 & & & \\
\hline & AS alcohol & 0.786 & 0.007 & & & \\
\hline & AS $\omega$-hydroxy fatty acid & 0.691 & 0.027 & & & \\
\hline \multirow[t]{6}{*}{ Subsoils } & D fatty acid & 0.937 & 0.019 & AS alcohol & 0.904 & 0.035 \\
\hline & D alcohol & 0.907 & 0.034 & & & \\
\hline & D alkane & 0.882 & 0.048 & & & \\
\hline & AI fatty acid & 0.903 & 0.036 & & & \\
\hline & AI alcohol & 0.917 & 0.029 & & & \\
\hline & AS alcohol & 0.969 & 0.006 & & & \\
\hline
\end{tabular}

${ }^{\mathrm{a}} \mathrm{D}$, AS and $\mathrm{AI}$ refer to $\mathrm{DCM} / \mathrm{MeOH}$ soluble fraction, $\mathrm{DCM} / \mathrm{MeOH}$ soluble fraction of IPA/NH 3 extract and $\mathrm{DCM} / \mathrm{MeOH}$ insoluble fraction of IPA/ $\mathrm{NH}_{3}$ extract, respectively. ${ }^{\mathrm{b}}$ Linear correlation coefficient. ${ }^{\mathrm{c}}$ Significance.

Ester-bound fatty acids and $\omega$-hydroxy fatty acids occurred in all leaves and roots, whereas the leaves and roots of hawthorn had the highest abundance of fatty acids of all leaves and the highest $\omega$-hydroxy fatty acids of all roots (Table 4). Much fewer ester-bound alcohols were observed in leaves than in roots. The hawthorn roots had the most abundant alcohol group. As expected, no $\alpha, \omega$-dicarboxylic acids were present in leaves but only in roots.

\subsubsection{Soil-vegetation link based on compound groups}

Figure 3 shows the relative concentrations of the compound groups subdivided between topsoils and subsoils. Interestingly, although the composition within each compound group is different, there is almost no significant difference between the concentrations of compound groups in topsoils and subsoils. The relative abundance of AI $\alpha, \omega$-dicarboxylic acids in the topsoils was significantly higher than in the subsoils $(p=0.013)$, while such compounds are only derived from roots. There was no significant difference between the relative abundances of all other summed compound groups between topsoils and subsoils. Although more extractable fatty acids were found in leaves than in roots, except for sea-

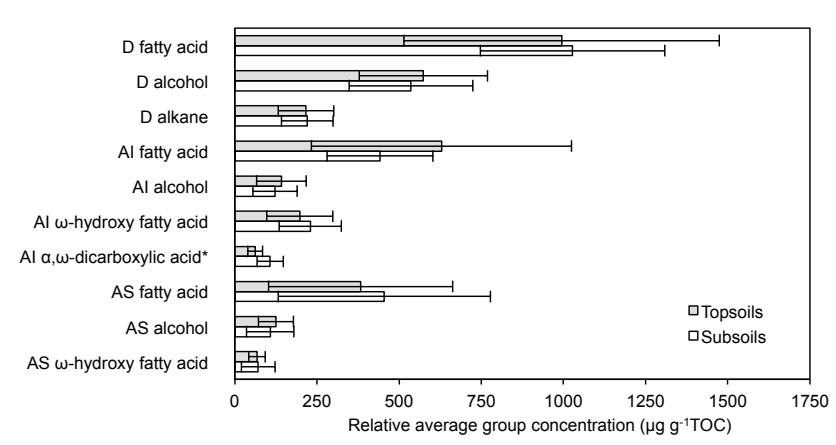

Figure 3. The relative average concentrations $\left(\mu \mathrm{gg}^{-1} \mathrm{TOC}\right)$ of compound groups in the topsoils and subsoils. Error bars represent standard deviations of concentrations for compound groups. * Means significant differences between topsoils and subsoils.

buckthorn (Table 4), no clear differences for D fatty acids were observed between topsoils and subsoils (Fig. 3). The amounts of $\mathrm{D}$ alkanes in topsoils and subsoils were almost equal, while leaves had much more alkanes than roots. Comparing the AI fraction, AI fatty acids were equal in the topsoils and subsoils (Fig. 3), while the ester-bound fatty acids 
Table 4. The group abundances of both $\mathrm{DCM} / \mathrm{MeOH}$ extractable lipids and ester-bound lipids upon $\mathrm{BF}_{3}-\mathrm{MeOH}$ hydrolysis of leaves and roots $\left(\mu \mathrm{g} \mathrm{g}^{-1}\right.$ dried material).

\begin{tabular}{|c|c|c|c|c|c|c|c|c|c|c|c|}
\hline \multirow[b]{3}{*}{ Lipid type } & \multirow[b]{3}{*}{ Compound name } & \multicolumn{10}{|c|}{ Vegetation species } \\
\hline & & \multirow{2}{*}{$\begin{array}{l}\text { Festuca ovina } \\
\text { (sheep fescue) } \\
\text { Leaves + roots }\end{array}$} & \multirow{2}{*}{$\begin{array}{r}\text { Hypnum Lacunosum } \\
\text { (hypnum moss) } \\
\text { Whole plants }\end{array}$} & \multicolumn{2}{|c|}{$\begin{array}{l}\text { Hippophae } \\
\text { rhamnoides } \\
\text { (sea-buckthorn) }\end{array}$} & \multicolumn{2}{|c|}{$\begin{array}{l}\text { Crataegus sp. } \\
\text { (hawthorn) }\end{array}$} & \multicolumn{2}{|c|}{$\begin{array}{l}\text { Pinus nigra } \\
\text { (black pine) }\end{array}$} & \multicolumn{2}{|c|}{$\begin{array}{l}\text { Quercus robur } \\
\text { (common oak) }\end{array}$} \\
\hline & & & & Leaves & Roots & Leaves & Roots & Needles & Roots & Leaves & Roots \\
\hline \multirow[t]{3}{*}{ Extractable } & fatty acid & 771.5 & 103.1 & 125.3 & 902.4 & 49.2 & 145 & 35.2 & 27.8 & 598 & 109.6 \\
\hline & alcohol & 632.6 & 55.7 & 413.7 & 236.9 & 394.7 & 53.3 & 65.6 & 25.7 & 1105.6 & 47.6 \\
\hline & alkane & 109.3 & 18.0 & 284.3 & 84.9 & 2263.1 & 0.0 & 0.0 & 2.7 & 50.8 & 0.0 \\
\hline \multirow[t]{4}{*}{ Ester-bound } & fatty acid & 1170.2 & 927.4 & 336.5 & 994.9 & 1320.6 & 128.7 & 566.8 & 327.2 & 574.1 & 97.4 \\
\hline & alcohol & 37.9 & 3.7 & 0.0 & 544.4 & 0.0 & 851.8 & 51.0 & 201.8 & 2.5 & 455.1 \\
\hline & $\omega$-hydroxy fatty acid & 1382.6 & 51.1 & 39.8 & 821.6 & 274.0 & 1369.2 & 2053.6 & 229.4 & 161.6 & 1037.2 \\
\hline & $\alpha, \omega$-dicarboxylic acid & 0.0 & 0.0 & 0.0 & 175.3 & 0.0 & 284.2 & 0.0 & 25.5 & 0.0 & 414.7 \\
\hline
\end{tabular}

were more abundant in leaves than in roots (Table 4). The $\omega$ hydroxy fatty acids were slightly lower in the topsoils than in the subsoils, whereas the concentration of this group was lower in leaves than in roots.

\subsubsection{Quality relationship of two compound groups to SWR}

From the above analysis, individual compound groups in absolute concentrations ( $\mu \mathrm{g} \mathrm{g}^{-1}$ soil) were in general able to describe the SWR behaviour, while using the relative amounts ( $\mu \mathrm{g} \mathrm{g}^{-1} \mathrm{TOC}$ ) were not. As a next step, we analysed the ratio of two different compound groups reflecting a quality parameter of SWR markers in relation to SWR. To understand if this quality factor is able to describe the SWR, the linear correlation of such a ratio and SWR was analysed. For all soils, AS alcohol was essential for a significant combination (Table 5). When AS alcohol was the numerator, the correlation between the ratio of two groups and SWR was positive, otherwise, it was negatively correlated. Also for the topsoils and the subsoils, AS alcohol occurred in all significant combinations and had a positive relationship when AS alcohol was the numerator. In contrast to across all soils, for the topsoils, not all the groups that combined with AS alcohol showed a significant relation. Among those significant combinations, all three compound groups from the D fraction were included; however, AI alcohol was the only group from the AI fraction, while AS fatty acid was the only one from the AS fraction. For the subsoils, it is interesting that significant combinations coincided with all AI compound groups except AI alcohol. None of the significant combinations were the same for the topsoils and subsoils. All the significant combinations for the top-/subsoils were also obtained in those for all soils. Similar to all soils, AS alcohol as the numerator achieved positive correlations between the quality ratios and SWR for the topsoils.

For the topsoils, all the groups from the $\mathrm{D}$ fraction were included in the significant combinations. Linking those groups to the extractable lipids of the plant leaves, oak leaves had the highest concentrations of both fatty acids and alcohols.
All the D fraction groups were abundant in the roots of seabuckthorn. The leaves and the roots of hawthorn had the highest abundances of ester-bound alcohols. For the subsoils, among the significant combinations, all three AI groups, i.e. fatty acid, $\omega$-hydroxy fatty acid and $\alpha, \omega$-dicarboxylic acid, occurred in the ester-bound lipids of vegetation. The ester-bound fatty acids were most abundant in the leaves of hawthorn and the roots of sea-buckthorn (Table 4). Hawthorn roots were richer in $\omega$-hydroxy fatty acids than the other plant roots, whereas pine needles had the highest $\omega$-hydroxy fatty acids for all leaves. $\alpha, \omega$-Dicarboxylic acids were richest in oak roots.

\section{Discussion}

\subsection{Single SWR markers}

As known, the extracted SWR markers are all hydrophobic (Hansel et al., 2008; Atanassova and Doerr, 2010; de Blas et al., 2013); however, significant negative correlations still have been shown in relative abundance. For all soil categories, compared to long-chain compounds, the short-chain ones showed more negative linear relationships with SWR. Atanassova and Doerr (2010) also detected more abundant short-chain dicarboxylic acids in less water repellent soils. Mainwaring et al. (2004) mentioned low molecular weight polar compounds diffuse quickly through soil water. A possible explanation of those more negative relationships is that the short-chain compounds are supposed to be more mobile and less hydrophobic, inducing a relative lower SWR. Since the measured SWR is an average value reflecting the contribution of all components, the contribution of the short-chain compounds to cause SWR is apparently relatively smaller than the average contribution induced by all SWR markers resulting in negative relations. In addition, it also implies that other long-chain compounds have a relatively larger contribution to SWR, which is supported by the positive relations. Soil organic matter composition and hence SWR markers differ between soils under various vegetation. From either the ecological or chemical point of view, the influence of single 
Table 5. Correlation coefficients and significance levels of combinations of two SWR marker groups significantly $(<0.05)$ related to SWR based on the quality factor (Group1/Group2)

\begin{tabular}{lllrc}
\hline Soil category & Group1 $^{\mathrm{a}}$ & Group2 & Coef. $^{\mathrm{b}}$ & Sig. $^{\mathrm{c}}$ \\
\hline \multirow{2}{*}{ All soils } & D fatty acid & AS alcohol & -0.710 & 0.003 \\
& AS alcohol & D alcohol & 0.658 & 0.008 \\
& AS alcohol & D alkane & 0.645 & 0.010 \\
& AS alcohol & AI fatty acid & 0.681 & 0.005 \\
& AS alcohol & AI alcohol & 0.689 & 0.050 \\
& AS alcohol & AI $\omega$-hydroxy fatty acid & 0.631 & 0.012 \\
& AS alcohol & AI $\alpha, \omega$-dicarboxylic acid & 0.654 & 0.008 \\
& AS alcohol & AS fatty acid & 0.607 & 0.016 \\
& AS $\omega$-hydroxy fatty acid & AS alcohol & -0.579 & 0.024 \\
\hline \multirow{2}{*}{ Top soils } & D fatty acid & AS alcohol & -0.680 & 0.030 \\
& AS alcohol & D alcohol & 0.661 & 0.037 \\
& AS alcohol & D alkane & 0.637 & 0.048 \\
& AS alcohol & AI alcohol & 0.664 & 0.036 \\
& AS alcohol & AS fatty acid & 0.642 & 0.045 \\
\hline Subsoils & AS alcohol & AI fatty acid & 0.993 & 0.001 \\
& AS alcohol & AI $\omega$-hydroxy fatty acid & 0.955 & 0.011 \\
& AS alcohol & AI $\alpha, \omega$-dicarboxylic acid & 0.925 & 0.024 \\
\hline
\end{tabular}

${ }^{a} \mathrm{D}, \mathrm{AS}$ and $\mathrm{AI}$ refer to $\mathrm{DCM} / \mathrm{MeOH}$ soluble fraction, $\mathrm{DCM} / \mathrm{MeOH}$ soluble fraction of IPA/ $/ \mathrm{NH}_{3}$ extract and

$\mathrm{DCM} / \mathrm{MeOH}$ insoluble fraction of IPA/NH 3 extract, respectively. ${ }^{\mathrm{b}}$ Linear correlation coefficient. ${ }^{\mathrm{c}}$ Significance.

SWR markers on SWR cannot be accurately quantified, and thus, single compounds are not good SWR markers for predict the extent of SWR well.

\subsection{Role of compound groups}

Since single SWR markers may not be capable of predicting SWR, we analysed the possible correlations between compound groups and SWR. We are the first to discuss the quantity and quality of SWR markers for predicting SWR. For all soils, the positive relationships between the absolute amounts of all the compound groups and SWR follow the significant positive relationship between TOC and SWR shown by Mao et al. (2014). Therefore, it is not surprising that the absolute quantity of the single SWR marker groups demonstrated its capability for predicting SWR. However, the quality of compounds is more important than the quantity because of its influence on SWR (Lozano et al., 2013). Regarding the relative concentrations of SWR marker groups, AS alcohol was the only group to show a significant relationship with SWR for all soils and subsoils. In addition, alcohols have been detected in water repellent soils and associated with SWR (Mainwaring et al., 2004; Hansel et al., 2008; Atanassova and Doerr, 2010). As AS alcohol does not comprise an abundant group in all AS extracts, the relationship between compound groups and SWR might not simply be explained by only a single compound group. Therefore, the ratio of two different groups, namely the quality of the compound groups in our study, was used to demonstrate the significant combinations predicting SWR for different soil categories.
For the topsoils, there are fewer groups from the AI and AS fractions combined with AS alcohol that were significantly related to SWR than for all soils. For instance, $\alpha, \omega$ dicarboxylic acids in the AI fraction and $\omega$-hydroxy fatty acids in both AI and AS fractions in combination with AS alcohols did not predict SWR well in topsoils. It is reasonable that those combinations were no longer significant because of the different original sources of SWR markers. The main source of SWR markers in the topsoils is most likely plant leaves (Bull et al., 2000a; Naafs et al., 2004), whereas both $\alpha, \omega$-dicarboxylic acids and $\omega$-hydroxy fatty acids are typically derived from roots (Kolattukudy, 1981, 2001; Pollard et al., 2008). For the subsoils, the entire $\mathrm{D}$ fraction originating from leaf waxes was not involved in the significant combinations with AS alcohol, suggesting that only little contribution of organic compounds to the sandy subsoils is from leaves (Nierop and Verstraten, 2004). All three groups that successfully combined with AS alcohol are from the root-derived AI fraction, revealing that the primary source of organic matter for subsoils is roots (Bull et al., 2000b; Nierop et al., 2006), and those combinations could well predict the subsoil SWR.

$\mathrm{AI}$ alcohol was not on the list of significant group combinations for the subsoils but was the only AI group present in one significant combination for the topsoils, potentially implying that AI alcohol combined with AS alcohol can be a good predictor of SWR in the topsoils. Based on the analysis of the significant combinations of the topsoils and subsoils, the original source of SWR markers probably plays a vital role in selecting best combinations to predict soil SWR. 
However, the relationships observed between SWR marker groups and SWR may not be directly applicable to other types of soils with different soil texture, structure and vegetation cover (Bisdom et al., 1993; Doerr et al., 2000; De Blas et al., 2010).

\subsection{Role of the AS fraction}

Interestingly, only AS alcohol was positively related to SWR significantly. It implies that SWR is higher when the soil organic matter contains relatively greater amounts of AS alcohol. In addition, AS alcohol most frequently appeared in significant group combinations. Although the AS fraction seems to be an important SWR fraction, compared to the other two fractions, the AS fraction contained the least amount of extracted SWR markers, the AS fraction as such and its origin is poorly understood. Mao et al. (2014) speculated that the AS fraction physically blocked by the suberin-derived AI fraction are mainly from leaves and a smaller part from roots. However, in this paper we have shown the following:

1. As observed earlier, there were no alkanes in the AS fractions (Mao et al., 2014), while in the present study alkanes was one of the main groups present in leaves while barely or not-at-all present in roots, suggesting a negligible leaf signal in the AS fraction.

2. The $\omega$-hydroxy fatty acids in the AS fraction were mainly $\mathrm{C}_{22}$ and $\mathrm{C}_{24}$, which are typical of suberinderived compounds from roots (Kolattukudy, 1980; Nierop et al., 2006; Spielvogel et al., 2014).

3. For the subsoils, only the ratios of AS alcohol/AI compounds had significant positive relationships with SWR. Here AI compounds included AI fatty acid, AI $\omega$ hydroxy fatty acid and AI $\alpha, \omega$-dicarboxylic acid, which are suberin-derived compounds (Mao et al., 2014). Those significant combinations suggest that the origin of AS alcohol may be relevant to the origin of the AI fraction, namely roots. AS alcohol / AI alcohol was the only ratio of AS alcohol / AI compounds that did not predict SWR in the subsoil well, implying that AI alcohol is different to some degree from the other AI groups when it is associated with AS alcohol.

4. For the topsoils, the ratio of AS alcohol / AI compounds (except AI alcohol) did not have strong correlations with SWR. AI compounds mainly originate from roots, demonstrating that root-derived compounds possibly do not respond to the SWR of the topsoils. For the topsoils, the ratio of AS alcohol / AI alcohol was significantly related to SWR, implying that the relationship between AS alcohol and AI alcohol is unique and different than the relationships between AS alcohol and other AI compounds.
5. $\omega$-Hydroxy fatty acid group in the AI fraction had a positive significant relationship $(r=0.58, p=0.02)$ with AS alcohol, but none of the compound groups in the D fraction correlated well with AS alcohol. As previously pointed out, the D fraction and AI fraction are mainly derived from leaf-waxes and roots, respectively (Mao et al., 2014). The correlations reflect that the AS alcohol did not have the same original source as D compounds but probably originate from the same source as AI compounds. All arguments together suggest that roots are the likely main original source of the AS fraction.

As described in our previous study, the AS fraction does not directly have contact with water in soils as it is physically blocked by the AI fraction by definition (Mao et al., 2014). The DCM-MeOH insoluble larger ester-bound components in the AI fraction can be turned into an AS fraction through microbial-hydrolysis-producing monomeric compounds that are extractable (Fernando et al., 1984; Martins et al., 2014). Kolattukudy (2001) proposed a structure of suberin in which $\omega$-hydroxy fatty acids and $\alpha, \omega$-dicarboxylic acids are ester bonded to form (linear) polymers. Possessing only one functional group, alcohols are likely bound to the edge of such large molecules. Upon degradation, these alcohols could be hydrolysed to become monomers easier than $\omega$-hydroxy fatty acids and $\alpha, \omega$-dicarboxylic acids which both contain two functional groups that occur more inside the polymers. $\alpha, \omega$ Dicarboxylic acids were not found in the AS fraction, which may imply that their position within the suberin polymers is apparently different from that of the $\omega$-hydroxy fatty acids through which they are less easily hydrolysed than the other groups.

We speculate that an AI fraction turns into an AS fraction through microbial hydrolysis. The greater the microbial activity in soils, the more decomposed of organic matter becomes (Schnürer and Rosswall, 1982), and as a result a larger amount of a given AI fraction could be transformed into an AS fraction. Consequently, according to linear regression analysis, the larger the AS fraction, the stronger SWR gets. Over time, when the AI fraction decreases through microbial hydrolysis, the amount of the AS fraction increases and the SWR is raised until the remaining AI fraction becomes too small to cover the whole AS fraction. As such, the ratio of AS / AI fractions becomes an indicator of the optimal SWR. Once part of the AS fraction is no longer blocked by the AI fraction and becomes directly extractable by DCM-MeOH, it automatically becomes part of the D fraction. Before that, the role of AS fraction may be a kind of catalyst that binds (and is blocked by) the predominantly root-derived AI fraction to mineral soil particles, meanwhile inducing SWR. The proportion of the AS fraction in soil organic matter may be an important predictor of SWR.

If we extrapolate this from the molecular level to the level of young soils, the amount of organic matter is small. Therefore, microbial activity is also small and only a small amount 
of AS fraction can be produced, and thus SWR is relatively small. When the soil becomes more developed, there is more organic matter and more time to produce a larger AS fraction, and the SWR also becomes higher. Over time, when organic matter input and output is in equilibrium, the size of the AS fraction may also become stable; the level of SWR for that particular soil may become stable as well. As the AS fraction is mainly derived from roots and is produced upon microbial hydrolysis of the predominantly root-derived AI fractions, we expect plants with larger root biomass in older, more developed soils will lead to the highest SWR. Compared to shrubs and trees, smaller plants such as grasses and mosses which have smaller and thinner root systems and produces smaller organic matter contents will likely cause smaller SWR.

\subsection{Plant signals in soils}

Soil organic matter composition of different soils varies largely due to differences in vegetation cover (Van Bergen et al., 1997; Nierop, 2001; Kögel-Knabner, 2002). In this study, the main groups of the extractable and ester-bound lipids present in the leaves and roots were, in general, all identified in D, AS and AI fractions of the soils under the given vegetation. No significant difference between the summed relative abundances of the groups (except $\mathrm{AI} \alpha, \omega$-dicarboxylic acid) in the topsoils and subsoils was found in our study. This means that the signals of leaves and roots are mixed in both topsoils and subsoils potentially due to a mixed cover of vegetation sources or vegetation succession at the field site. In such a situation, AI $\alpha, \omega$-dicarboxylic acids still showed significantly higher concentrations in the subsoils than in the topsoils, strongly reflecting the root contribution to the subsoils.

The covering plants are the main sources of the SWR markers and the extractable and ester-bound lipids in soils reflect, therefore, the leaf and root signals of these plants (Nierop et al., 2003; Naafs et al., 2004). Within the extractable lipids, alkanes and alcohols are more suitable than fatty acids for indicating the origin of the soil lipids since fatty acids are not sufficiently specific for use as biomarkers (Van Bergen et al., 1997; Jansen et al., 2006). The $C_{27}$ and $\mathrm{C}_{29}$ alkanes are the dominating alkanes in all soils analysed (Mao et al., 2014); they were also the major alkanes found in most of our vegetation leaves, strongly suggesting a close relationship between the soil alkanes and those occurring in plant leaves (Bull et al., 2000a; Naafs et al., 2004; Nierop et al., 2006). Since $\mathrm{C}_{26}$ alcohol is typical of grass (Walton, 1990; Van Bergen et al., 1997), which predominated both the sheep fescue and the soils under sheep fescue (Mao et al., 2014), implying that $C_{26}$ alcohol in the soils most likely indeed originated mainly from grasses. Similarly, $\mathrm{C}_{24}$ alcohol, which is an indicator of oak leaves (Bull et al., 2000a, b), was abundant in the soils under oak. Regarding the alcohol group, more alcohols were observed in leaves than in roots and more alcohols were found in the topsoils than in the subsoils, suggesting a large contribution of extractable lipids from plant leaf waxes to the directly underlying (top)soils.

The ester-bound lipid biomarkers represent the cutin and suberin-derived compounds in the plant leaves/needles and roots, respectively. $\alpha, \omega$-Dicarboxylic acids are typically derived from suberins (Kolattukudy, 2001), which were only found in roots, and similar to the ester-bound alcohols and $\omega$-hydroxy fatty acids, they were more enriched in subsoils rather than in topsoils, implying that the organic matter in the sandy subsoils well reflects a root origin (e.g. Nierop et al., 2006). The small amounts of $\alpha, \omega$-dicarboxylic acids in the topsoils may derive from shallow-root plants such as grasses providing suberins to the topsoils. An alternative source may be bark, which also contains suberins albeit their contribution to soils is smaller than that of roots (Preston et al., 1994). As aforementioned, the AS fraction most likely has mainly the same root origin as the AI fraction.

\section{Conclusions}

The prediction of SWR from the quantity of the SWR markers follows the relationship between soil TOC and SWR. The relative amounts of most single short-chain SWR markers negatively relate to SWR, while the long-chain markers have positive but insignificant relationships with SWR. This implies that a single SWR marker is not suitable to explain and predict the behaviour of SWR. The analysis of the quality of SWR marker groups suggests that AS alcohol combined with suberin-derived $\omega$-hydroxy fatty acids and $\alpha, \omega$-dicarboxylic acids can well predict the SWR of subsoils. For the topsoils, the combination AS alcohol / AI alcohol is a good predictor of the SWR. The relatively more AS alcohol a soil contains, the more water repellent it becomes. The relationships between the SWR of sandy soils and SWR markers may not be entirely suitable for other types of soils, as soil textures and structures may impact it differently. A combined number of indications suggest that in this study the AS fraction is mainly root-derived and likely produced by microbial hydrolysis of ester-bound lipids. Together, roots produce markers that induce SWR stronger than above-ground plant tissues, and root-derived compounds more sufficiently predict SWR. Understanding to what extent this holds for other soil types with different textures and structures needs further research.

Acknowledgements. This study is funded by the Earth and Life Science and Research Council (ALW) with financial aid from the Netherlands Organization for Scientific Research (NWO) (grant 821.01.004). The authors thank PWN for permitting our research in the Zuid-Kennemerland National Park and J. A. Hageman for helping with the geostatistical analysis of data.

Edited by: S. Doerr 


\section{References}

Atanassova, I. and Doerr, S.: Organic compounds of different extractability in total solvent extracts from soils of contrasting water repellency, Eur. J. Soil Sci., 61, 298-313, doi:10.1111/j.13652389.2009.01224.x, 2010.

Bisdom, E. B. A., Dekker, L. W., and Schoute, J. F. Th.: Water repellency of sieve fractions from sandy soils and relationships with organic material and soil structure, Geoderma, 56, 105-118, doi:10.1016/0016-7061(93)90103-R, 1993.

Bond, R. D. and Harris, J. R.: The influence of the microflora on physical properties of soils. I. Effects associated with filamentous algae and fungi, Aust. J. Soil Res., 2, 111-122, 1964.

Buczko, U., Bens, O., and Hüttl, R. F.: Variability of soil water repellency in sandy forest soils with different stand structure under Scots pine (Pinus sylvestris) and beech (Fagus sylvatica), Geoderma, 126, 317-336, doi:10.1016/j.geoderma.2004.10.003, 2005.

Bull, I. D., Van Bergen, P. F., Nott, C. J., Poulton, P. R., and Evershed, R. P.: Organic geochemical studies of soils from the Rothamsted Classical Experiments - V. The fate of lipids in different long-term soil experiments, Org. Geochem., 31, 389-408, doi:10.1016/S0146-6380(00)00008-5, 2000a.

Bull, I. D., Nott, C. J., Bergen, P. F. Van, Poulton, P. R., and Evershed, R. P.: Organic geochemical studies of soils from the Rothamsted classical experiments - VI. The occurrence and source of organic acids in an experimental grassland soil, Soil Biol. Biochem., 32, 1367-1376, doi:10.1016/S00380717(00)00054-7, 2000b.

Contreras, S., Cantón, Y., and Solé-Benet, A.: Sieving crusts and macrofaunal activity control soil water repellency in semiarid environments: Evidences from SE Spain, Geoderma, 145, 252258, doi:10.1016/j.geoderma.2008.03.019, 2008

DeBano, L. F.: The role of fire and soil heating on water repellency in wildland environments: a review, J. Hydrol., 231-232, 195206, doi:10.1016/S0022-1694(00)00194-3, 2000.

de Blas, E., Rodríguez-Alleres, M., and Almendros, G.: Speciation of lipid and humic fractions in soils under pine and eucalyptus forest in northwest Spain and its effect on water repellency, Geoderma, 155, 242-248, doi:10.1016/j.geoderma.2009.12.007, 2010.

de Blas, E., Almendros, G., and Sanz, J.: Molecular characterization of lipid fractions from extremely water-repellent pine and eucalyptus forest soils, Geoderma, 206, 75-84, doi:10.1016/j.geoderma.2013.04.027, 2013.

Dekker, L. W. and Ritsema, C. J.: How water moves in a water repellent sandy soil: 1 . Potential and actual water repellency, Water Resour. Res., 30, 2507-2517, doi:10.1029/94WR00749, 1994.

Dekker, L. W. and Ritsema, C. J.: Preferential flow paths in a water repellent clay soil with grass cover, Water Resour. Res., 32, 1239-1249, doi:10.1029/96WR00267, 1996.

Doerr, S. H., Shakesby, R. A., and Walsh, R. P. D.: Soil water repellency: its causes, characteristics and hydro-geomorphological significance, Earth-Sci. Rev. 51, 33-65, doi:10.1016/S00128252(00)00011-8, 2000.

Doerr, S. H., Llewellyn, C. T., Douglas, P., Morley, C. P., Mainwaring, K. A., Haskins, C., Johnsey, L., Ritsema, C. J., Stagnitti, F., Allinson, G., Ferreira, A. J. D., Keizer, J. J., Ziogas, A. K., and Diamantis, J.: Extraction of compounds associated with water re- pellency in sandy soils of different origin, Aust. J. Soil Res., 43, 225-237, doi:10.1071/SR04091, 2005.

FAO: World reference base for soil resources 2006, Rome, 2006.

Feeney, D. S., Hallett, P. D., Rodger, S., Bengough, A. G., White, N. A., and Young, I. M.: Impact of fungal and bacterial biocides on microbial induced water repellency in arable soil, Geoderma, 135, 72-80, doi:10.1016/j.geoderma.2005.11.007, 2006.

Fernando, G., Zimmermann, W., and Kolattukudy, P. E.: Suberingrown Fusarium solani f. sp pisi generates a cutinase-like esterase which depolymerizes the aliphatic components of suberin, Physiol. Plant Pathol., 24, 143-155, doi:10.1016/00484059(84)90022-5, 1984.

Franco, C. M. M., Tate, M. E., and Oades, J. M.: Studies on nonwetting sands. I. The role of intrinsic particulate organic-matter in the development of water-repellency in non-wetting sands, Aust. J. Soil Res., 33, 253-263, doi:10.1071/SR9950253, 1995.

Franco, C. M. M., Clarke, P. J., Tate, M. E., and Oades, J. M.: Hydrophobic properties and chemical characterisation of natural water repellent materials in Australian sands, J. Hydrol., 231232, 47-58, doi:10.1016/S0022-1694(00)00182-7, 2000.

Hallett, P. D. and Young, I. M.: Changes to water repellence of soil aggregates caused by substrate-induced microbial activity, Eur. J. Soil Sci., 50, 35-40, doi:10.1046/j.1365-2389.1999.00214.x, 1999.

Hansel, F. A., Aoki, C. T., Maia, C. M. B. F., Cunha Jr., A., and Dedecek, R. A.: Comparison of two alkaline treatments in the extraction of organic compounds associated with water repellency in soil under Pinus taeda, Geoderma, 148, 167-172, doi:10.1016/j.geoderma.2008.10.002, 2008

Horne, D. J. and McIntosh, J. C.: Hydrophobic compounds in sands in New Zealand-extraction, characterisation and proposed mechanisms for repellency expression, J. Hydrol., 231-232, 35-46, doi:10.1016/S0022-1694(00)00181-5, 2000.

Jansen, B., Nierop, K. G. J., Hageman, J. A., Cleef, A. M., and Verstraten, J. M.: The straight-chain lipid biomarker composition of plant species responsible for the dominant biomass production along two altitudinal transects in the Ecuadorian Andes, Org. Geochem., 37, 1514-1536, doi:10.1016/j.orggeochem.2006.06.018, 2006.

Kleber, M., Sollins, P., and Sutton, R.: A conceptual model of organo-mineral interactions in soils: self-assembly of organic molecular fragments into zonal structures on mineral surfaces, Biogeochemistry, 85, 9-24, doi:10.1007/s10533-0079103-5, 2007.

Kögel-Knabner, I.: The macromolecular organic composition of plant and microbial residues as inputs to soil organic matter, Soil Biol. Biochem., 34, 139-162, 2002.

Kolattukudy, P. E.: Biopolyester membranes of plants: cutin and suberin, Science, 208, 990-1000, doi:10.1126/science.208.4447.990, 1980.

Kolattukudy, P. E.: Structure, biosynthesis and biodegradation of cutin and suberin, Ann. Rev. Plant Physio., 32, 539-567, doi:10.1146/annurev.pp.32.060181.002543, 1981.

Kolattukudy, P. E.: Polyesters in higher plants, in: Advances in Biochemical Engineering/Biotechnology, edited by: Scheper, T., Springer, Berlin, Heidelberg, 1-49, 2001.

Krammes, J. S. and DeBano, L. F.: Soil Wettability?: A neglected factor in watershed management, Water Resour. Res., 1, 283 286, doi:10.1029/WR001i002p00283, 1965. 
Lozano, E., Jiménez-Pinilla, P., Mataix-Solera, J., Arcenegui, V., Bárcenas, G. M., González-Pérez, J. A., García-Orenes, F., Torres, M. P., and Mataix-Beneyto, J.: Biological and chemical factors controlling the patchy distribution of soil water repellency among plant species in a Mediterranean semiarid forest, Geoderma, 207-208, 212-220, doi:10.1016/j.geoderma.2013.05.021, 2013.

Mainwaring, K., Hallin, I. L., Douglas, P., Doerr, S. H., and Morley, C. P.: The role of naturally occurring organic compounds in causing soil water repellency, Eur. J. Soil Sci., 64, 667-680, doi:10.1111/ejss.12078, 2013.

Mainwaring, K. A., Morley, C. P., Doerr, S. H., Douglas, P., Llewellyn, C. T., Llewellyn, G., Matthew, I., and Stein, B. K.: Role of heavy polar organic compounds for water repellency of sandy soils, Environ. Chem. Lett., 2, 35-39, doi:10.1007/s10311004-0064-9, 2004.

Mao, J., Nierop, K. G. J., Sinninghe Damsté, J. S., and Dekker, S. C.: Roots induce stronger soil water repellency than leaf waxes, Geoderma, 232-234, 328-340, doi:10.1016/j.geoderma.2014.05.024, 2014.

Martins, I., Hartmann, D. O., Alves, P. C., Martins, C., Garcia, H., Leclercq, C. C., Ferreira., R., He, J., Renaut, J., Becker, J. D., and Silva Pereira, C.: Elucidating how the saprophytic fungus Aspergillus nidulans uses the plant polyester suberin as carbon source, BMC Genomics, 15, 613, doi:10.1186/1471-216415-613, 2014.

Ma'Shum, M., Tate, M. E., Jones, P., and Oades, J. M.: Extraction and characterization of water-repellent materials from Australian soils, J. Soil Sci., 39, 99-110, doi:10.1111/j.13652389.1988.tb01198.x, 1988.

McGhie, D. A. and Posner, A. M.: Water repellence of a heavy textured Western Australian surface soil, Aust. J. Soil Res., 18, 309323, doi:10.1071/SR9800309, 1980.

McGhie, D. A. and Posner, A. M.: The effect of plant top material on the water repellence of fired sands and water-repellent soils, Aust. J. Agric. Res., 32, 609-620, doi:10.1071/AR9810609, 1981.

Metson, A. J.: Methods of chemical analysis for soil survey samples, New Zealand Soil Bureau Bulletin 12, Government Printer, Wellington, 22, 1956.

Michel, J. C., Riviere, L. M., and Bellon-Fontaine, M. N.: Measurement of the wettability of organic materials in relation to water content by the capillary rise method, Eur. J. Soil Sci., 52, 459467, doi:10.1046/j.1365-2389.2001.00392.x, 2001.

Morley, C. P., Mainwaring, K. A., Doerr, S. H., Douglas, P., Llewellyn, C. T., and Dekker, L. W.: Organic compounds at different depths in a sandy soil and their role in water repellency, Aust. J. Soil Res., 43, 239-249, 2005.

Naafs, D. F. W., Van Bergen, P. F., Boogert, S. J., and De Leeuw, J. W.: Solvent-extractable lipids in an acid andic forest soil; variations with depth and season, Soil Biol. Biochem., 36, 297-308, doi:10.1016/j.soilbio.2003.10.005, 2004.

Neris, J., Jiménez, C., Fuentes, J., Morillas, G., and Tejedor, M.: Vegetation and land-use effects on soil properties and water infiltration of Andisols in Tenerife (Canary Islands, Spain), Catena, 98, 55-62, doi:10.1016/j.catena.2012.06.006, 2012.

Nierop, K. G. J.: Temporal and vertical organic matter differentiation along a vegetation succession as revealed by pyrolysis and thermally assisted hydrolysis and methylation, J. Anal. Appl. Pyrol., 61, 111-132, doi:10.1016/S0165-2370(01)00132-2, 2001.

Nierop, K. G. J. and Verstraten, J. M.: Rapid molecular assessment of the bioturbation extent in sandy soil horizons under pine using ester-bound lipids by on-line thermally assisted hydrolysis and methylation-gas chromatography/mass spectrometry, Rapid Commun. Mass Sp., 18, 1081-1088, doi:10.1002/rcm.1449, 2004.

Nierop, K. G. J., Naafs, D. F. W., and Verstraten, J. M.: Occurrence and distribution of ester-bound lipids in Dutch coastal dune soils along a pH gradient, Org. Geochem., 34, 719-729, doi:10.1016/S0146-6380(03)00042-1, 2003.

Nierop, K. G. J., Naafs, D. F. W., and Van Bergen, P. F.: Origin, occurrence and fate of extractable lipids in Dutch coastal dune soils along a pH gradient, Org. Geochem., 36, 555-566, doi:10.1016/j.orggeochem.2004.11.003, 2005.

Nierop, K. G. J., Jansen, B., Hageman, J. A., and Verstraten, J. M.: The complementarity of extractable and ester-bound lipids in a soil profile under pine, Plant Soil, 286, 269-285, doi:10.1007/s11104-006-9043-1, 2006.

Pollard, M., Beisson, F., Li, Y., and Ohlrogge, J. B.: Building lipid barriers: biosynthesis of cutin and suberin, Trends Plant Sci., 13, 236-246, doi:10.1016/j.tplants.2008.03.003, 2008.

Poulenard, J., Michel, J. C., Bartoli, F., Portal, J. M., and Podwojewski, P.: Water repellency of volcanic ash soils from Ecuadorian paramo: effect of water content and characteristics of hydrophobic organic matter, Eur. J. Soil Sci., 55, 487-496, doi:10.1111/j.1365-2389.2004.00625.x, 2004.

Preston, C. M., Hempfling, R., Schulten, H. R., Schnitzer, M., Trofymow, J. A., and Axelson, D. E.: Characterization of organic matter in a forest soil of coastal British Columbia by NMR and pyrolysis-field ionization mass spectrometry, Plant Soil, 158, 6982, doi:10.1007/BF00007919, 1994.

Riederer, M., Matzke, K., Ziegler, F., and Kögel-Knabner, I.: Occurrence, distribution and fate of the lipid plant biopolymers cutin and suberin in temperate forest soils, Org. Geochem., 20, 10631076, doi:10.1016/0146-6380(93)90114-Q, 1993.

Rodríguez-Alleres, M. and Benito, E.: Spatial and temporal variability of surface water repellency in sandy loam soils of NW Spain under Pinus pinaster and Eucalyptus globulus plantations, Hydrol. Process., 25, 3649-3658, doi:10.1002/hyp.8091, 2011.

Rodríguez-Alleres, M. and Benito, E.: Temporal fluctuations of water repellency in forest soils of Galicia, NW Spain. Do soil samples dried at laboratory reflect the potential soil water repellency?, Hydrol. Process., 26, 1179-1187, doi:10.1002/hyp.8209, 2012.

Schnürer, J. and Rosswall, T.: Fluorescein diacetate hydrolysis as a measure of total microbial activity in soil and litter, Appl. Environ. Microbiol., 43, 1256-1261, 1982.

Schulten, H. R. and Leinweber, P.: New insights into organicmineral particles: composition, properties and models of molecular structure, Biol. Fert. Soils. 30, 399-432, doi:10.1007/s003740050020, 2000.

Spielvogel, S., Prietzel, J., Leide, J., Riedel, M., Zemke, J., and Kögel-Knabner, I.: Distribution of cutin and suberin biomarkers under forest trees with different root systems, Plant Soil, 381, 95-110, doi:10.1007/s11104-014-2103-z, 2014.

Van Bergen, P. F., Bull, I. D., Poulton, P. R., and Evershed, R. P.: Organic geochemical studies of soils from the Rothamsted classical 
experiments - I. Total lipid extracts, solvent insoluble residues and humic acids from Broadbalk Wilderness, Org. Geochem., 26, 117-135, doi:10.1016/S0146-6380(96)00134-9, 1997.

Van't Woudt, B. D.: Particle coatings affecting the wettability of soils, J. Geophys. Res., 64, 263-267, doi:10.1029/JZ064i002p00263, 1959.

Van Wesemael, J. C. H.: De bepaling van het Calciumcarbonaatgehalte van Gronden, Chemisch Weekblad, 51, 35-36, 1955.

Walton, T. J.: Waxes, cutin and suberin, in: Methods in Plant Biochemistry, edited by: Harwood, J. L. and Bowyer, J. R., Academic Press, London, 105-158, 1999.
Wessel, A. T.: On using the effective contact angle and the water drop penetration time for classification for water repellency in dune soils, Earth Surf. Proc. Land, 13, 555-561, doi:10.1002/esp.3290130609, 1988.

Zavala, L. M., García-Moreno, J., Gordillo-Rivero, Á. J., Jordán, A., and Mataix-Solera, J.: Natural soil water repellency in different types of Mediterranean woodlands, Geoderma, 226-227, 170178, doi:10.1016/j.geoderma.2014.02.009, 2014. 